\title{
Shang ritual animals: colour and meaning (part 2)
}

\author{
Wang Tao \\ School of Oriental and African Studies and University College London \\ wt@soas.ac.uk
}

\begin{abstract}
Following on from Part 1 of this article (BSOAS 70/2, 305-372), Part 2 continues to examine the use of colour in different diviner groups, but focuses on the groups belonging to the non-kings' school. It also includes the newly discovered inscriptions from the eastern section of Huayuanzhuang in Yinxu. The exercise of colour preference in the non-kings' school is similar to that seen in the kings' school, but reveals an even broader interest. By looking at the context in which each colour was used, we can detect the process of a colour system working in Shang rituals. The final section of the paper provides a cross-cultural comparison of Shang colour symbolism which had a profound influence on the late wuxing theory.
\end{abstract}

\section{The non-kings' school}

\section{The Wu- and Zi-groups}

In comparison with the inscriptions belonging to the kings' diviner school, the so-called non-kings' inscriptions are quite distinctive in both form and content. Although they share some common features in their form of ancestral worship, the non-kings' inscriptions contain many ancestral titles that are not found in the list of royal genealogy. For example, some of the recipients of sacrifices are only seen in the $\mathrm{Wu}$ - and $\mathrm{Zi}$-groups, such as $\mathrm{Zu} \mathrm{Ji}$ 祖己, $\mathrm{Zu}$ Xin 祖辛, $\mathrm{Zu}$ Ren 祖壬, Bi Yi 妣乙, Fu Bing 父丙, Fu Ding 父丁, Fu Ji 父己, Zi Geng 子庚, Zi Meng 子夢, Nei Yi 内乙, Nei Ji 内己, Si Wu 司戊, Wai Wu 外戊, Shi Jia 石甲, Tian Geng 天庚, Tian Wu 天戊 and Hei Yi 黑乙 in the Wu-group; and Long Jia 龍甲, Long Mu 龍母, Si Gui 司癸, Xiao Ji 小乙 and many ladies (zhufu 諸婦) in the Zi-group. This suggests that the records may have belonged to a comparatively independent kinship system, probably to the houses of the queens, princes, or heads of different royal branch lineages, rather than to the kings themselves.

The exercise of preference and the choice of ritual animals of a particular colour is evident in the non-kings' school, as well as in the inscriptions of the kings' school. For example, white and multicoloured animals are specially indicated in the sacrifice to important ancestors. Heji: 19849 is a small fragment of turtle shell, but the inscription is very important:

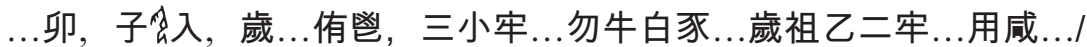
祝...

... mao/Zi X/enter/slaughter/ ... /offer/aromatic-wine/three/small/ penned-sheep/ ... /multicolour/ox/white/pig/ ... /slaughter/Zu Yi/two /penned-ox/ ... /use/Xian/ ... /huil ... /pray ...
} 
... mao day, Prince $\mathrm{X}$ enters, to perform the slaughtering sacrifice to

... offering of aromatic wine, and three small penned sheep ... multicoloured oxen and white pigs ... the slaughtering sacrifice to Grandfather Yi of two penned oxen ... to use for Ancestor Xian of ... it should be ... to make the prayer ...

Although its fragmentary condition poses some difficulty to the reader, its content and style of calligraphy indicate that this inscription should belong to the Zi-group. ${ }^{1}$ It is clear that the ritual was conducted by a prince or head of a royal clan. The numbers, types and colours of sacrificial animals are specifically mentioned: multicoloured oxen and white pigs, together with two penned oxen and three penned sheep; the other offering is aromatic wine. They are the sacrifice for the ancestors. The recipients of the sacrifice include Grandfather Yi and the ancestor Xian, who was the founder of the Shang dynasty. The inscription also indicates the specific method by which the animals are slaughtered: sui is a ritual slaughtering frequently employed in Shang rituals, probably using bronze or jade axes. The basic features of the ancestral rite are no different from those of the other diviner groups of the kings' school, and are particularly close to those of the Shi-group.

Other important ancestors such as Yang Jia, Father Jia, Father Ding and their consorts also receive sacrifices in the non-kings' group. For example:

Heji: $11209^{2}$

甲申....侑子...部白豕

jiashen/ ... /sacrifice/Zi/Xiang [Jia]/white/pig

... on jiashen (day 21) ...to make the sacrifice, Prince ... to Xiang [Jia] of white pigs.

Heji: 21538

...父甲三白豖, 至...

... /Fu Jia/three/white/pig/zhi-rite $3 / \ldots$

... to Father Jia three white pigs are offered; ... in performing the $z h i$-rite ...

Tunnan: $2670^{4}$

丙子卜: 燎白羊豕...父丁泚癸, 卯常...

1 The editors of the Heji have classified it as of the Shi-group, and a different transcription of the inscription is found in Yao Xiaosui 姚孝遂 (ed.-in-chief), Yinxu jiagu keci moshi zongji 殷墟甲骨刻辭摹釋總集 (Beijing: Zhonghua shuju, 1988), 440.

2 This inscription is classified in the Bin-group by the Heji editors, but its calligraphic style suggests that it should probably belong to the Zi-group.

3 The character zhi 至 means "to arrive", but here seems to refer to a kind of sacrificial rite. For the decipherment of the graph, see $\mathrm{Yu}$ Xingwu 于省吾 (ed. in chief), Jiaguwenzi gulin 甲骨文字詁林 [hereafter JGWZGL] (Beijing: Zhonghua shuju, 1996), 2560.

4 The style of calligraphy of this inscription is like that in Zhongguo shehuikexueyuan lishiyanjiusuo, Hu Huoxuan and Guo Moruo (eds in chief), Jiaguwen heji 甲骨文合 集 [hereafter Heji] (Beijing: Zhonghua shuju, 1978-82), 11209, and is close to that of 
bingzi/crack/burn/white/sheep/pig/ ... /Fu Ding/Bi Gui/cut/ $/ \mathrm{x}^{5} / \ldots$

Cracking made on bingzi (day 13), to perform the burning-sacrifice of white sheep and pigs unto Father Ding and Ancestress Gui ... to cut open x-animal ...

Here, the recipients of the sacrifices are Father Jia, Father Ding and Ancestress Bi Gui; the ritual animals are white pigs and sheep; and the methods of sacrifice are burning and cutting the animals.

In the non-kings' school inscriptions, the methods of ritual are as rich as those of the kings' school. And in addition to slaughtering, burning and cutting, animals are also used in blood-sacrifice. For example:

Yincang: 1891

戊寅卜, 盟牛于妣庚/戊寅卜, 燎白豕卯牛于妣庚/戊寅卜, 盟三羊 wuyin/crack/blood-sacrifice/ox/to/Bi Geng/wuyin/crack/burn/white/ pig/cut/ox/to/Bi Geng/wuyin/crack/blood-sacrifice/three/sheep

Cracking made on wuyin (day 15), we make the blood-sacrifice of oxen to Ancestress Geng.

Cracking made on wuyin, we perform the burning sacrifice of white pigs and to cut open oxen to Ancestress Geng.

Cracking made on wuyin, we make the blood-sacrifice of three sheep.

Heji: 1912 is a very similar inscription, bearing the same date, which may come from the same divination set. In these inscriptions, white pigs are recorded as being used as a blood-sacrifice to Ancestress Bi Geng, and are probably associated with the fertility rite. As previously noted, in the $\mathrm{Zi}$ group, a number of divinations are about female ancestors and on topics such as fertility or childbearing. In these examples the style of calligraphy is neat and soft, very delicate and feminine. Thus, several scholars have speculated that they were probably made under the supervision of the queens' or kings' consorts, and that the diviners and scribes themselves may have been women. ${ }^{6}$

As discussed in Part 1 of this article (BSOAS 70/2, 305-372), when divinatory charges are made in the paired or choice-chain types, the divination is set out to provide a number of alternatives regarding the type, number and colour of the ritual animals for the offering. This formula is also seen in the non-kings' school. For example, Heji: 21955 is a small fragment and its divinatory charges read:

the Shi-group, but the authors of the Xiaotun report have identified it as a Wugroup inscription. Here, I tentatively follow their view.

5 This graph has not been deciphered yet, but it seems to depict an animal or human victim.

6 See Chen Mengjia 陳夢家 Yinxu buci zongshu 殷墟卜辭綜述 (Beijing: Kexue chubanshe, 1956), 165-7; also Li Xueqin, “Di Yi shidai de feiwang buci” 帝乙時代 的非王卜辭, Kaogu xuebao 考古學報 1958/1, 43-74, where Li expresses a similar view and calls the group of inscriptions related to the Zi-group "women's inscriptions". 
惠白豕/惠犅/惠犅羊

hui/white/pig/hui/bull /hui/male/sheep

It should be white pigs that are to be sacrificed.

It should be bulls that are to be sacrificed.

It should be rams that are to be sacrificed.

Judging from the style of the calligraphy, this inscription is probably also from the hand of a $\mathrm{Zi}$-group diviner. Although fragmentary in form, it is surely a divination made specifically about sacrificial animals, asking what is the most appropriate offering: rams, bulls or white pigs.

Several inscriptions show that white animals are used as a means of exorcism, as we saw for the Li-group inscriptions (see part 1 of this article, BSOAS 70/2, 305-372). For example: Heji: 22046 is a large turtle plastron that bears numerous divinatory charges. I have translated the charges dating from the same day to show the complexity of, and interrelationships between, the divinatory charges. They are concerned with the methods of ritual, types of sacrifice, and the appropriate date and method of divination. The diviner also recorded the use of white pigs.

戊子卜, 至...子庚...洷...禦父丁 .../弜至/戊子卜, 至, 子禦兄庚姜牢 /戊子卜, 至, 子禦父丁白豕/戊子卜, 侑歲于父戊, 用今戊/戊子卜, /惠今 戊用/戊子卜，用六卜

wuzi/crack/zhi-rite 8 /... /Zi Geng/zhi-rite/ ... /exorcism/Fu Ding ... / not/arrive/wuzi/crack/zhi-rite/Zi/exorcism/Xiong Geng/Qiang/ penned-ox/wuzi/crack/zhi-rite/Zi/exorcism/Fu Ding/white/pig/wuzil crack/offer/x-rite/slaughter/to/Fu Wu/use/present/wu/wuzi/crack/huil present/wu/use/wuzi/crack/use/six/crack

Cracking made on wuzi (day 25), in performing the zhi-rite... Prince Geng ...

In performing the $z h i$-rite/Father Ding ...

It will not arrive.

Cracking made on wuzi, in performing the zhi-rite, the prince makes the exorcist ritual to Brother Geng with Qiang tribesmen and penned oxen.

Cracking made on wuzi, in performing the zhi-rite, the prince makes the exorcist ritual to Father Ding with white pigs.

Cracking made on $w u z i$, we make offering of the $\mathrm{x}$-rite and slaughtering sacrifices to Father $\mathrm{Wu}$; and it will take place on the present $w u$ day.

7 Scholars' decipherment of this character differs; some read it as a verb, "to cut forcefully", but many argue that it should be understood as a reference to the sex of the oxen; see JGWZGL: 2833. In the Liji, there is an adjectival noun xinggang 騂剛, which the commentary notes as "red bull"; see Sun Xidan 孫希旦 (1736-84), Liji jijie 禮記集解, juan 31 (Beijing: Zhonghua shuju, 1986), 850.

8 For the decipherment of this character, see $J G W Z G L: 2560$. Its original meaning is "to arrive", but here it is probably used as a ritual name. See earlier note 3. 
Cracking made on $w u z i$, it should be the present $w u$ day when the sacrifice is made.

Cracking made on wuzi, to crack the bones six times.

In this inscription, the divinatory charges concern the sacrifice, and when and how the divination should be done. The ritual offerings include penned oxen, Qiang human victims and white pigs. The animals are slaughtered in the ritual but, most importantly, it is $\mathrm{Zi}$, the prince himself, who performs the exorcist ritual to $\mathrm{Zi} \mathrm{Geng,} \mathrm{Xiong} \mathrm{Geng,} \mathrm{Fu} \mathrm{Ding} \mathrm{and} \mathrm{Fu}$ Wu. These four are unique to the Wu-group. In several other examples, the ritual is also performed to a person who is probably a member of the lineage. For example:

\section{Heji: 22073 \\ 乙酉卜, 禦新于父龙白猳/乙酉卜, 禦新于妣辛白盧豕 yiyou/crack/exorcism/Xin'/to/Fu Wu/white/boar/yiyou/crack/ exorcism/Xin/to/Bi Xin/white/black(?) ${ }^{10} /$ pig \\ Cracking made on yiyou (day 22), in performing the exorcist ritual for Xin, we make sacrifice to Father Wu of white boars. \\ Cracking made on yiyou, in performing the exorcist ritual for Xin, we make sacrifice to Ancestress Xin of white and black pigs.}

In this case, the exorcism rite is performed to Father $\mathrm{Wu}$ and his consort, Ancestress Xin. The paired divinatory charges are about the different offerings for the different ancestors. The colours of the ritual animals are white and black.

Here, we need to explain the phrase "bai lu shi" 白盧豕 or "white-blackpigs" in which the word $l u$ is clearly used after an adjective indicating colour. Several scholars have insisted that the character is used as a verb that, if in the correct order, should precede the colour term bai, meaning "to strip the white pigs". ${ }^{11}$ However, this reading does not fit too well with the context, unless we treat it as a scribal error. It is better to seek an alternative explanation. In later texts, the word 盧 can also be used as an adjective denoting the colour of objects, meaning "dark"; for instance, in

9 In OBI the character xin 新 is usually used as an adjective, "new", and it can sometimes be rendered as a verb meaning "to fire" or "to chop up"; see JGWZGL: 2528 and Zhao Cheng's 趙誠, Jiaguwen jianming cidian 甲骨文簡明詞典 (Beijing: Zhonghua shuju, 1988), 246. But in this case it could also be understood as a proper name, referring to an ancestor of the $\mathrm{Zi}$ clan, to whom the exorcist ritual is being performed; see Li Xueqin and Peng Yushang, Yinxu jiagu fenqi yanjiu, 315. Li Xiaoding 李孝定 thought that the word after xin is missing here; see Li Xiaoding, Jiaguwen jishi 甲骨文集釋 (Taibei: Zhongyan yanjiuyuan lishi yuyan yanjiusuo zhuankan 50, 1965), 4097.

10 The character $l u$ 盧 is sometimes used as a verb, “to strip"; see JGWZGL: 2208. Also, in the Shijing (Maoshi: 103) we see the phrase lu lingling 盧令令, the commenary for which notes that $l u$ refers to a tian quan 田犬 “field dog” (Maoshi zhengyi, juan 5.2; SSJZS, 353).

11 See JGWZGL: 2217; see also Zhao Cheng, Jiaguwen jianming cidian, 313. 
the Shangshu, phrases such as lu gong 盧弓 “black bow" and lu shi 盧矢 "black arrow" can be found. ${ }^{12}$ Wang Xianqian 王先謙, in his Shiming shuzhen 釋名疏証, also explains that "black soil is called lu” ( $\mathrm{tu}$ hei yue lu 土黑曰盧). ${ }^{13}$ If we read the word $l u$ as a colour term used attributively to describe the animals in OBI, then it is very interesting to note that the $l u s h i$ 盧豕 (black pig) or lu quan 盧犬 (black dog) appear in the non-kings' inscriptions only, and are used exclusively as a sacrifice for female ancestors. $^{14}$

\section{The Huayuanzhuang Zi-group}

The newly discovered inscriptions from the eastern section of Huayuanzhuang contain important evidence for the study of colour in the non-kings' school. The style of the calligraphy of the inscriptions in this group is distinctive and, though less accomplished, in many ways similar to that of the Shi-group, which may suggest a comparatively early date. There are many uncommon usages which are found only in this group. In the inscriptions, sacrifice is frequently made to ancestors of the Shang genealogy, such as Shang Jia 上甲, Da Yi 大乙, Da Jia 大甲, Zu Geng 祖庚, $\mathrm{Zu}$ Xing 祖辛, $\mathrm{Zu}$ Ding 祖丁, $\mathrm{Zu} \mathrm{Wu}$ 祖戊 and Xiong Ding 兄丁, and most especially to $\mathrm{Zu} \mathrm{Yi}$ 祖乙, $\mathrm{Zu}$ Jia 祖甲 and their consorts, but rarely to pre-dynastical ancestors. Other natural spirits such as Yue 岳 and He 河 are rarely mentioned.

The most frequently occurring name in the inscriptions is $\mathrm{Zi}$-prince, who was served by the diviners. He often acted as the prognosticator and prayer in divinations. Judging by the number and content of the inscriptions, this group probably belonged to an important clan leader or minister in the early to middle reign of King Wu Ding. There are a number of inscriptions that mention Fu Hao 婦好 or Lady Hao, the famous consort of King Wu Ding. Here, the identity of the prince is problematic. Yang Shengnan 楊升 南 has argued that "Zi" was Xiao Ji 孝己, the son of King Wu Ding. ${ }^{15}$ It is clear that he was closely associated with the royal house, and with Lady Hao in particular. However, strangely, there are few direct references to the king (wang 王) himself.

If we look at the colour of ritual animals in this group, we find numerous inscriptions in which animals of various colours - white, black and

12 Shangshu zhengyi, juan 20; (SSJZS, 254).

13 Wang Xianqian, Shimin shuzhen (repr. Shanghai, 1984), 18. For a further discussion of the etymology of the character, see Shen Jianshi 沈兼士 (1886-1947), Shen Jianshi xueshu lunwen ji, 沈兼士學術論文集 (repr. Beijing: Zhonghua shuju, 1986), $307-10$

14 See Heji: 19956, 19957, 19958, 19970, 20576. 21804, 22048, 22065, 22077, 22098, 22209, 22210, 31993, Tunnan: fu-2.

15 Yang Shengnan, "Yinxu huadong H3buci 'zi'de zhuren shi Wu Ding taizi Xiao Ji”殷墟花东H3卜辞“子”的主人是武丁太子孝己, in Wang Yuxin 王宇信, Song Zhenghao 宋镇豪 and Meng Xianwu 孟宪武 (eds), 2004 nian Anyang Yinshang wenming guoji xueshu taolunhui lunwenji 2004 年安阳殷商文明国际学术研讨会论文 集 (Beijing: Shehui kexue wenxian chubanshe, 2004), 204-10. See also Liu Yuan 劉 源, “Yinxu Huayuanzhuang dongdi jiaguwen yanjiu gaikuang”殷墟花園莊东地甲 骨文研究概況 Lishi yanjiu 歷史研究 2005/2, for a summary of different views. 
dark-red - are specifically indicated in the context of the ancestral cult. For example, Huayuanzhuang: 4 is a large turtle plastron on which the inscriptions are filled with black pigments. Four divination charges are read:

\section{甲寅, 歲祖甲白猳一, 祐㜽一, 筬自西祭/甲寅, 歲祖甲白豘一

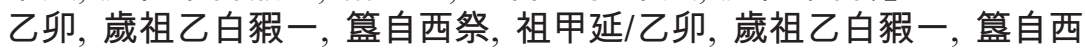 祭, 祖甲延 \\ jiayin/slaughter/Zu Jia/white/boar/one/offer ${ }^{16} /$ aromatic-wine/one/ food-offering ${ }^{17} /$ from/west/meat-rite/jiayin/slaughter/Zu Jia/white/ boar/one yimao/slaughter/Zu Yi/white/boar/one /food-offering/from/ west/meat-rite/Zu Jia/continue/yimao/slaughter/Zu Yi/white/boar/one/ food-offering/from/west/meat-rite/Zu Jia/continue \\ On jiayin (day 51), we will perform the slaughtering sacrifice to Grandfather Jia of one white boar, and additionally of one jar of aromatic wine; food-offering starting from the west side with the meat-sacrifice.}

On jiayin, we will perform the slaughtering sacrifice to Grandfather Jia of one white sow.

On yimao (day 52), we will perform the slaughtering sacrifice to Grandfather Yi of one white boar; food-offering starting from the west side with the meat-sacrifice, Grandfather Jia then receives sacrifice again.

On yimao, we will perform the slaughtering sacrifice to Grandfather Jia of one white boar; food-offering starting from the west side with the meat-sacrifice; Grandfather Jia then receives sacrifice again.

Here, the divinatory charges are repeated. On jiayi day, white boars and sows were chosen for the sacrifice to Grandfather Jia, and on yimao day, white boars were again chosen for Grandfather Yi. At the same time, sacrifices were displayed on the "west side". This may suggest the spatial arrangement of the ancestors in temples, similar to the later "zhaomu” 昭穆 system which placed ancestors according to the left and right branches.

We can cite further examples in which white pigs, including the wild species, are offered to the ancestors, together with penned sheep and aromatic wine. Sometimes even the ways of slaughtering animals are described. For example:

\section{Huayuanzhuang: 29}

\section{乙巳, 歲祖乙白氮一, 又答, 祖乙永}

yisi/slaughter/Zu Yi/white/wild pig/one/have/food-offering/Zu Yi/ forever

16 This graph depicts food being offered on an altar and is transcribed as you here.

17 This graph depicts a food container and is transcribed as gui 筬 here, and probably means food offered in vessels. 
On yisi (day 42), we will perform the slaughtering sacrifice to Grandfather Yi of one white wild pig, and additionally of foodoffering; this is extended to Grandfather Yi.

Huayuanzhuang: 296 bears a similar inscription which mentions white wild boars as the sacrifice to $\mathrm{Zu} \mathrm{Yi}$, and the divination is also made on yisi day. The other regular recipients include Ancestress Bi Geng, who is offered a sacrifice at the same time as the male ancestors:

\section{Huayuanzhuang: 53}

歲泚庚白踟

Slaughter/Bi Geng/white/wild pig

We will perform the slaughtering sacrifice to Ancestress Geng of white wild pigs.

Huayuanzhuang: 267

庚戌, 侑祭妣庚, 又白㒸一

gengxu/offer ${ }^{18} /$ meat-rite/Pi Geng/have/white/sow/one

On gengxu (day 47), we make an offering of the meat-rite to Ancestress Geng, and additionally of one white sow.

Huayuanzhuang: 309

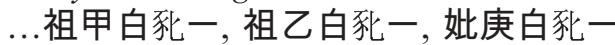

... Zu Jia/white/sow/one/Zu Yi/white/sow/one/Pi Geng/white/sow/one

... to Grandfather Jia of one white sow; to Grandfather Yi of one white sow; to Ancestress Geng of one white sow.

Significantly, in a number of inscriptions, the use of the particle hui shows that the white pigs are specifically chosen for the ancestors. For example:

\section{Huayuanzhuang: 63}

乙卯卜, 惠白豕祖甲不用/乙卯, 歲祖乙猳一, 祐䀢一 yimao/crack/hui/white/pig/Zu Jia/not/use/yimao/slaughter/Zu Yi/boar/ one/have/aromatic-wine/one

Cracking made on yimao (day 52), and it should be white pigs that are not used for Gandfather Jia.

On yimao, we will perform the slaughtering sacrifice to Grandfather Yi of one boar, and offer one jar of aromatic wine.

Here, the divination charges are concerned with the different sacrifices to $\mathrm{Zu}$ Jia and $\mathrm{Zu} \mathrm{Yi}$. The divination is whether or not white pigs should be used as a sacrifice to $\mathrm{Zu}$ Jia.

Huayuanzhuang: 181 is another turtle plastron on which a series of divinatory charges are made on jia 甲, $j i$ 己, geng 庚, xin 辛 and ren 壬 days;

18 The character here is written as $\forall$, and is very close to $x$. It may have been intended as a graphic distinction between the character you 侑 (a ritual name) and the particle you 有 ("have", "plus"). 
and on the $j i$ day the divination is about the rituals and sacrifices to Ancestress Geng. Among the divinatory charges is a special mention of the use of white pigs in exorcist ritual:

\section{己卜，惠多臣禦往于妣庚/己卜，惠白豕于妣庚，又出 /歲牝于妣庚，又 出/歲牡于妣庚, 又媰 \\ si/crack/hui/many/minister/exorcism/go/to/Bi Geng/si/crack/hui/white/ pig/to/Bi Geng/offer/aromatic-wine/slaughter/cow/to/Bi Geng/have/ aromatic-wine/slaughter/boar/to/Bi Geng/have/aromatic-wine Cracking on si day, it should be several ministers who perform the exorcist ritual addressed to Ancestress Geng. \\ Cracking on si day, it should be white pigs that are to be sacrificed to Ancestress Geng, and additionally aromatic wine. \\ To perform the slaughter rite to Ancestress Geng of cows, and additionally aromatic wine. \\ To perform the slaughter rite to Ancestress Geng of boars, and additionally aromatic wine.}

The function of the divination charges is to determine who should perform the exorcist ritual to $\mathrm{Bi}$ Geng and the most appropriate sacrifice. The ritual animals include white pigs, bulls, cows and rams. The colour of the ritual animal, like its sex, and the number to be sacrificed, is an important factor in the selection process.

Sometimes, the ways in which animals are killed are complex. For example:

Huayuanzhuang: 115

甲寅, 歲祖甲牝, 歲祖乙, 白豕, 歲妣庚羍, 祖甲创䢃卯

jiayin/slaughter/Zu Jia/cow/slaughter/Zu Yi/white/pig/slaughter/Pi

Geng/penned-sheep/Zu Jia/blood-sprinkle/strip(?) ${ }^{19} /$ cut

On jiayin (day 51), we perform the slaughtering sacrifice to Grandfather Jia of cows; the same slaughtering sacrifice to Grandfather Yi of penned sheep and white pigs; the same slaughtering sacrifice to Ancestress Geng of penned sheep; animals to Grandfather Jia are for blood sprinkling, stripping up and cutting in half.

In Shang royal genealogy, $\mathrm{Zu}$ Jia and $\mathrm{Zu}$ Yi are considered very important ancestors, as is the ancestress Bi Geng. As we saw in the kings' inscriptions, the preference for white animals is probably related to the high status of the ancestors. $^{20}$

19 This character is written as $\Psi_{x}$, which appears in Heji 6057 (r) as a place name beipi 北毗 “northern territory". But here it is most probably a verb, and I have I tentatively translated it as $p i$ 䢃 “to strip up".

20 The authors of the Huayuanzhuang report also point this out; see Yinxu Huayuanzhuang, 1558. 
Sometimes, the preference for whiteness in ritual offerings extended to objects such as ritual jade. For example:

Huayuanzhuang: 193

\section{乙亥, 子惠白圭稱。用。惟子若}

yihai/Zi/hui/white/jade-dagger/present ${ }^{21} /$ use/wei/Zi/approve

On yihai (day 12), the Prince should have white jade daggers

presented. Used. It is the Prince himself who approved this.

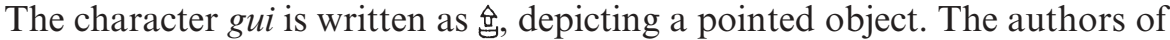
the Huayuanzhuang report cited Yu Xingwu's and Lao Gan's decipherments, arguing that the graph is the original form of character $j i$ 吉, which refers to a jade weapon. ${ }^{22}$ Many jade daggers and pointed tablets have indeed been discovered at Yinxu. White jade daggers were clearly favoured by the prince, as were white textiles. See, for example:

\section{Huayuanzhuang: 220}

甲申卜, 惠配乎曰婦好, 告白純。用/...卜, 子其入白純, 若 jiashen/crack/hui/Pei/call/Fu Hao/report/white/textile/use/ ... crack/Zi/ qi/send in/white/textile/approve

On jiashen (day 21), it should be Pei who calls upon on Lady Hao, and makes an announcement about white textiles. Used.

Cracking made on ... the Prince will send in white textiles and approves this.

The phrase baichun 白純 clearly refers to a kind of white textile, probably silk. It is interesting to read here that white silk was used in the ritual on behalf of Lady Hao. Interestingly, although no complete textiles have survived in the tomb of Lady Hao, there are about fifty bronzes on which silk fragments have been found. There is plenty of archaeological evidence to suggest that textile production was widespread in Shang times. ${ }^{23}$

Like the colour white, $w u$-multicolour seems equally to attract attention among the diviners in this group. For example, Huayuanzhuang: 37 records that multicoloured oxen and white pigs are used on different dates:

\section{癸酉卜, 惠勿牡歲甲祖。用}

guiyou/crack/hui/multicolour/bull/slaughter/Jia Zu/use

Cracking made on guiyou (day 10), it should be multicoloured bulls that are to be slaughtered to Jia, the Grandfather. Used.

21 The character probably refers to a way in which the jade objects were used. For its decipherment, see $J G W Z G L: 3110$.

22 Huayuanzhuang, 1635.

23 For a brief summary of the archaeological evidence, see Zhongguo shehui kexueyuan kaogu yanjiusuo 中國社會科學研究院考古研究所, Yinxu de faxian yu yanjiu 殷墟的發現與研究 (Beijing: Kexue chubanshe, 1994), 414-15. See also Vivi Sylwan, "Silk from the Yin dynasty", Bulletin of the Museum of Far Eastern Antiquities 9 (1937), 119-26. 
The same charge, repeated, and then on a different day:
乙卯卜, 惠白豕祖乙。不用/乙卯, 歲祖乙猳, 祐㜽一 yimao/crack/hui/white/pig/Zu Yi/not/use/yimao/slaughter/Zu Yi/boar/ offer/aromatic-wine/one
Cracking made on yimao (day 52), it should be white pigs for Grandfather Yi. Not used
On yimao, we will perform the slaughtering sacrifice to Grandfather $\mathrm{Yi}$ of boars, and offer one jar of aromatic wine.

Huayuanzhuang: 163 records that the exorcism ritual was addressed to Ancestress Geng, perhaps for the prince's toothache. Both white and multicoloured animals are mentioned in this inscription.

\begin{abstract}
庚午卜, 在奶, 禦子齒于妣庚, 冊牢, 勿牝, 白豕。用/...齒于妣庚, 冊牢, 勿牝, 白豕至豘一。用 genwu/crack/at/X ${ }^{24} /$ exorcist/Zi/teeth/to/Pi Geng/record $25 /$ penned-ox/ multicolour/cow/white/pig/use/ ... teeth/to/Pi Geng/record/penned-ox/ multicolour/cow/white/pig/to/sow/use

Cracking made on gengwu (day 43), at X, the exorcism rite performed for the Prince's toothache, to Ancestress Geng, and to make a pledge of penned oxen, multicoloured cows and white pigs. Used.

... the toothache healing ritual is performed to Ancestress Geng, and to make a pledge of penned oxen, multicoloured cows, white pigs, including sows. Used.
\end{abstract}

Huayuanzhuang: 142 has divinatory charges concerned with the various sacrifices that should be offered to Grandfather Yi. The prince himself makes the prayers:

\title{
祝, 于白牛用濊祖乙。用。子祝/祝, 于二牢用濊祖乙。用。子祝 乙亥, 噦祖乙二牢, 勿牛, 白氮, 祐出一, 子祝 \\ Pray/to/white/ox/use/ascend?/slaughter/Zu Yi/use/Zi/pray/pray/to/ two/penned-ox/use/x-rite/slaughter/Zu Yi/use/Zi/pray/yihai/x-rite/ slaughter/Zu Yi/two/penned-ox/multicolour/ox/white/wild pig/offer/ aromatic-wine/one/Zi/pray \\ In performing the praying-ritual, white oxen are used in the x-rite and slaughtering sacrifice to Grandfather Yi. Used. The Prince makes a prayer. \\ In performing the praying rite, two penned oxen are used in the x-rite and slaughtering sacrifice to Grandfather Yi. Used. The Prince makes a prayer.
}

24 A place name.

25 I have translated the character $c e$ 冊 as "to make a written record" elsewhere. But, as some other scholars argue, this character can also be understood as a verb, shan 刪, “to chop"; see JGWZGL: 2935, 2937. 
On yihai (day 12), we make the ascending and slaughtering sacrifice to Grandfather Yi of two penned oxen, multicoloured oxen, white pigs, and to offer one jar of aromatic wine; the Prince makes a prayer.

The ritual procedure here is very complicated. The intention behind the different sacrifices is to select the one most appropriate for Gandfather Yi.

In addition to the use of white and multicoloured offerings, in reading the Huayuanzhuang inscriptions one cannot fail to notice certain distinctive features of this group. Compared with the other diviners' groups, there is a far greater number of dark or black animals used in the ancestral cult. The most common is the antelope of red-dark colour. For example:

Huayuanzhuang: 34

辛卯卜, 子奠宜, 惠幽廌。用/辛卯卜, 子奠宜, 惠[幽廌]。不用 xinmao/crack/Zi/present ${ }^{26} /$ meat-display ${ }^{27} /$ hui/red-dark/antelope/use xinmao/crack/Zi/present/meat-display/hui/[red-dark/antelope]/not/use Cracking made on xinmao (day 28), the Prince makes presentation of the meat-displaying rite, and it should be antelopes of a red-dark colour. Used.

Cracking made on xinmao, the Prince makes presentation of the meatdisplaying rite, and it should be antelopes of red-dark colour. Not used.

Huayuanzhuang: 198 is a similar inscription found on a turtle plastron, in which the divinatory charges are about the exact date on which the ritual should take place, as well as the colour and sex of the ritual animals:

\footnotetext{
辛卯卜, 子奠宜, 至二日。用/辛卯卜, 子奠宜, 至三日。不用/辛卯卜, 惠 宜...或, 牝; 亦惠牡。用/辛卯卜, 子奠宜, 惠幽廌。用 xinmao/crack/Zi/present/meat-display/arrive/two/day/use/xinmao/ crack/Zi/present/meat-display/arrive/three/day/not/use/xinmao/crack/ huil.../meat-display/ ... /she-antelope $\mathrm{e}^{28} / \mathrm{cow} / \mathrm{also} /$ hui/bull/use/xinmaol crack/Zi/present/meat-display /hui/red-dark/antelope/use Cracking made on xinmao (day 28), the Prince makes presentation of the meat-displaying rite, till the second day. Used.

Cracking made on xinmao, the Prince makes presentation of the meatdisplaying rite, till the third day. Not used.

Cracking made on xinmao, it should be ... makes the meat-displaying rite ... sacrifice of she-antelopes and a cow; also it should be a bull. Used.

Cracking made on xinmao, the Prince makes presentation of the meatdisplaying rite, and it should be antelopes of red-dark colour. Used.
}

26 The original graph depicts a wine-offering can also be read as a verb, "to present"; see JGWZGL: 2718, 2719; see also Zhao Cheng, Jiaguwen Jianming cidian, 242.

27 This may refer to a particular rite in which ritual meat is displayed on a table; see Zhao Cheng, Jiaguwen jianming cidian, 240.

28 It is written as 3 , indicating that it is a female antelope. 
In these inscriptions, the prince himself was directly involved in and supervised the rituals. The divination seeks to determine how many days the sacrificial rite should last, and whether the dark-coloured antelopes should be used for the meat-displaying rite.

Huayuanzhuang: 149 is another large plastron on which the inscriptions are filled with red pigment. It shows that a series of divinations are made on jiaxu (day 11), jiawu (day 30), jihai (day 36), dingwei (day 44), gengwu (day 47), xinhai (day 48), jiayin (day 51) and guihai (day 60), in order to determine the proper ritual and sacrifice to $\mathrm{Zu}$ Jia, $\mathrm{Zu} \mathrm{Yi}$ and Bi Geng. On the jiaxu and jiayin days, the divinatory charges relate to the sacrifice to $\mathrm{Zu}$ Jia. White boars and red-dark antelopes are among the sacrifices:

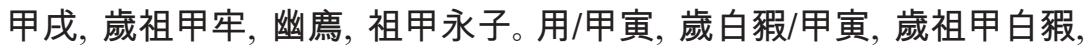 祐或一, 又笽 \\ jiaxu/slaughter/Zu Jia/penned ox/red-dark/antelope/Zu Jia/forever/Zi/ use/jiayin/slaughter/white/boar/jiayin/slaughter/Zu Jia/white/boar/ offer/aromatic-wine/one/have/food-offering \\ On jiaxu (day 11), we will perform the slaughtering sacrifice to Grandfather Jia of penned oxen and antelopes of red-dark colour; Grandfather Jia will forever protect the Prince. Used. \\ On jiayin (day 51), we will perform the slaughtering sacrifice of white boars. \\ On jiayin, we will perform the slaughtering sacrifice to Grandfather Jia of white boars, and offer one jar of aromatic wine, and additionally a food-offering.}

Huayuanzhuang: 237 has a similar inscription that is also filled with pigments: with red pigment on the lower section, and black on the upper. It records a series of divinations made on jiazi (day 1), yihai (day 2), xinwei (day 8), jiaxu (day 11), gengyin (day 27), jiayin (day 51), yimao (day 52) and dingsi (day 54). In the sacrificial cult, we read that the ritual animals addressed to $\mathrm{Zu}$ Jia are again white boars and red-dark antelopes:

\section{甲子, 歲祖甲白猳, 祐岀/惠白猳...祖甲/甲戌, 歲祖甲牢, 幽廌, 白猳, 祐 一出/甲戌, 歲祖甲牢, 幽廌, 白猳, 祐二出 \\ jiazi/slaughter/Zu Jia/white/boar/offer/aromatic-wine/hui/white/boar/ ... /Zu Jia/jiaxu/slaughter/Zu Jia/penned-ox/red-dark/antelope/white/ boar/offer/one/aromatic-wine/jiaxu/slaughter/Zu Jia/penned-ox/red- dark/antelope/white/boar/offer/two/aromatic-wine}

On jiazi (day 1), we will perform the slaughtering sacrifice of white boars to Grandfather Jia, and offer some aromatic wine.

It should be white boars ... to Grandfather Jia.

On jiaxu (day 11), we will perform the slaughtering sacrifice of penned oxen, red-dark antelopes, and white boars to Grandfather Jia, and offer one jar of aromatic wine.

On jiaxu, we will perform the slaughtering sacrifice of penned oxen, antelopes of red-dark colour, and white boars to Grandfather Jia, and offer two jars of aromatic wine. 
On the $y i$ day, the same sacrifice was made to $\mathrm{Zu} \mathrm{Yi}$ :

乙亥, 歲祖乙牢, 幽廌, 白猳, 祐出/乙亥, 歲祖乙牢, 幽廌, 白猳, 祐二苾 yihai/slaughter/Zu Yi/penned-ox/red-dark/antelope/white/boar/offer/ aromatic-wine/yihai/slaughter/Zu Yi/penned-ox/red-dark/antelope/ white/boar/offer/two/aromatic-wine

On yihai (day 12), we will perform the slaughtering sacrifice of penned oxen, antelopes of red-dark colour, and white boars to Grandfather $\mathrm{Yi}$, and offer some aromatic-wine.

On yihai we perform the slaughtering sacrifice of penned oxen, antelopes of red-dark colour, white boars to Grandfather Yi, and offer two jars of aromatic-wine.

In these cases, the only noticeable difference between the ritual sacrifices is the quantity of aromatic wine that is offered.

Compared with other diviner groups, black bulls seem to have occupied a unique position in the ancestral cult, in particular for $\mathrm{Zu} \mathrm{Yi}$. For example:

Huayuanzhuang: 49

丁丑, 歲祖乙黑牡一, 卯肑/丁丑, 歲祖乙黑牡一, 卯肑二于祖丁

dingchou/slaughter/Zu Yi/black/bull/one/cut/x-rite ${ }^{29} /$ dingchou/slaughter/Zu Yi/black/bull/one/cut/x-rite/two/to/Zu Ding

On dingchou (day 2), we will perform the slaughtering sacrifice to Grandfather Yi of one black bull, which is cut open and made into a meat-offering.

On dingchou, we will perform the slaughtering sacrifice to Grandfather Yi of one black bull, and cut open and make a meatoffering of two [oxen] for Grandfather Ding.

\section{Huayuanzhuang: 6}

甲辰夕, 歲祖乙黑牡一, 惠子祝, 若, 祖乙永。用。翌丁硅

jiachen/evening/slaughter/Zu Yi/black/bull/one/hui/Zi/pray/approve/

$\mathrm{Zu} \mathrm{Yi/forever/use/next/ding/dismember}$

On the evening of jiachen (day 41), we will perform the slaughtering sacrifice of one black bull to Grandfather Yi; it should be the Prince who makes a prayer and approves; Grandfather $\mathrm{Yi}$ is forever protecting. Used. The dismembering sacrifice is performed on the next ding day.

Huayuanzhuang: 67

\section{乙亥夕, 歲祖乙黑牝一, 子祝}

yihai/evening/slaughter/Zu Yi/black/cow/one/Zi/pray

In the evening of yihai (day 12), we will perform the slaughtering sacrifice of one black cow to Grandfather Yi; the Prince will make a prayer.

29 The character depicts a large fork and a piece of meat. It probably refers to a meatoffering rite. 
In the same inscription, the charge is repeated once more.

Huayuanzhuang: 252

乙亥, 歲祖乙黑牡一, 又兹一, ..子祝/乙亥, 歲祖乙黑牡一, 又羖, 笽, 子 祝

yihai/slaughter/Zu Yi/black/bull/one/have/she-goat ${ }^{30} /$ one/ ... /Zi/pray/ yihai/slaughter/Zu Yi/black/bull/one/have/ram/food/Zi/pray

On yihai (day 12), we will perform the slaughtering sacrifice to Grandfather Yi of one black bull, in addition to one she-goat ... the Prince makes a prayer.

On yihai, we will perform the slaughtering sacrifice to Grandfather Yi of one black bull, and additionally of rams, and the food-offering; the Prince makes a prayer.

The inscription on Huayuanzhuang: 319 has two identical divinatory charges, the one on the left is red, the one on the right black. It reads:

\section{乙丑, 歲祖乙黑牡一, 子祝, 骨禦峜, 在奶 yichou/slaughter/Zu Yi/black/bull/one/Zi/pray/Gu/exorcist/Zheng/at/ $\mathrm{X}$}

On yichou (day 2), we will perform the slaughtering sacrifice to Grandfather Yi of one black bull; the Prince makes a prayer; Gu performs the exorcism ritual to Zheng at $\mathrm{X}$.

Huayuanzhuang: 350

甲辰夕, 歲祖乙黑牡一, 子祝, 翌日砶

jiachen/evening/slaughter/Zu Yi/black/bull/one/Zi/pray/next/day/

dismember

On the evening of jiachen (day 41), we will perform the slaughtering sacrifice to Grandfather Yi of one black bull; the Prince makes a prayer, and on the next day, we will perform the dismembering sacrifice.

\section{Huayuanzhuang: 392}

\section{辛末, 歲祖乙黑牡, 祐苾一, 子祝}

xinwei/slaughter/Zu Yi/black/bull/offer/aromatic-wine/one/Zi/pray

On xinwei (day 8), we will perform the slaughtering sacrifice to Grandfather Yi of black bulls, and offer one jar of aromatic wine; the Prince makes a prayer.

Apart from Grandfather Yi, the Ancestress Geng is also frequently offered sacrifices of black oxen. For example:

Huayuanzhuang: $123^{31}$

辛酉旲, 歲妣庚黑牝一, 子祝/.../辛酉卜, 子其也支黑牝, 惟值往, 不雨; 用 妣庚...

30 The character consists of [羊] and [七], referring to a she-goat.

31 Huayuanzhuang: 175 and Huayuanzhuang: 437 bear the same inscription. 
xinyou/dust/slaughter/Pi Geng/black/cow/one/Zi/pray/...

xinyou/crack/Zi/qi/beat $32 /$ black/cow/wei/Zhi/go/not/rain/use/Pi Geng...

In the dust of xinyou (day 10), we will perform the slaughtering sacrifice to Ancestress Geng of one black cow; the Prince makes a prayer.

Cracking made on xinyou, the Prince will perhaps pefom the beatingritual of black cows. It should be Zhi who goes there, and there will be no rain. The sacrifice is used for Ancestress Geng ...

Huayuanzhuang: 178 records a number of divinations that are made on different dates: gengzi (day 37), guimao (day 41), yisi (day 42), jiyou (day 46), gengxu (day 47). The sacrifices include jades, human victims, wine and animals, of which black cows are specially offered in the blood sacrifice to Bi Geng:

癸卯夕, 歲妣庚黑牝一, 在入, 陟盟/陟盟。用 guimao/evening/slaughter/Pi Geng/black/cow/one/at/Ru/rise/bloodoffering/rise/blood-offering/use

In the evening of guimao (day 40), we perform the slaughtering sacrifice to Ancestress Geng of one black cow; at $\mathrm{Ru}$, to make an ascension and the blood sacrifice.

To make an ascension and the blood sacrifice. Used.

\section{Huayuanzhuang: 451}

己巳卜, 翌日庚歲妣庚黑牛, 又羊, 暮妓。用/庚午, 歲妣庚黑牡, 又羊, 子祝

jisi/crack/next/day/geng/slaughter/Pi Geng/black/ox/have/sheep/dust/ beat/use/gengwu/slaughter/Pi Geng/black/bull/have/sheep/Zi/pray

Cracking made on jisi (day 6), on the next geng day we will perform the slaughtering sacrifice to Ancestress Geng of black oxen, and additionally of sheep; and in the evening the victims are beaten. Used.

On gengwu (day 7), we will perform the slaughtering sacrifice to Ancestress Geng of black bulls, and additionally of sheep; the Prince makes a prayer.

\section{Huayuanzhuang: 150}

\section{己酉夕, 翌日砣妣庚黑牡一}

jiyou/evening/next/day/dismember/Pi Geng/black/bull/one

At the dusk of jiyou (day 46), on the next day we will perform the dismembering sacrifice to Ancestress Geng of one black bull.

32 The graph depicts a hand holding a stick beating a snake. It is used as a ritual name, probably indicating the way in which animals were killed; see $J G W Z G L$ : 1858. 
Huayuanzhuang: 457

己酉夕, 翌日矺歲妣庚黑牡一; 庚戌, 酊牝一

jiyou/evening/next/day/dismember/slaughter/Pi Geng/black/bull/one/ gengxu/cutting-rite/cow/one

At the dusk of jiyou (day 46), on the next day we will perform the dismembering and slaughtering sacrifice to Ancestress Geng of one black bull. On gengxu (day 47), we will perform the cutting-rite of one cow. ${ }^{33}$

In the rituals, the prince often makes the prayer, and in several cases his prayers are recorded, for example:

Huayuanzhuang: 161

辛末, 歲祖乙黑牡一, 祐出一; 子祝, 日: 毓祖非; 日: 云岂正祖惟? 日: 錄 盇不矺酠/乙亥夕, 歲祖乙黑牝一, 子祝

xinwei/slaughter/Zu Yi/black/bull/one/offer/aromatic-wine/one/Zi/ pray/say/ ancestor/grandfather/against/say/Yun Si/correct/grandfather/wei/say/Lu Tai/not/dismember/x-horse $34 / y$ ihai/evening/slaughter/ZuYi/black/cow/one/Zi/pray

On xinwei (day 8), we will perform the slaughtering sacrifice to Grandfather Yi of one black bull, and offer one jar of aromatic wine; the Prince makes the prayer, saying: "The ancestors are not pleased", saying: "Should Yun Si make correct sacrifices to the ancestors?", saying: "Lu Tai will not perform the dismembering rite of $\mathrm{x}$-horse". At dusk on yihai (day 12), the slaughtering sacrifice is performed to Grandfather Yi of one black cow; and the Prince makes a prayer.

\section{Huayuanzhuang: 220}

丁丑, 歲祖乙黑牡一, 卯肑; 子繙曰: 未有艱其至, 其戊。用 dingchou/slaughter/Zu Yi/black/bull/one/cut/meat-sacrifice/Zi/ prognosticate/say/wei/have/difficulty/qi/arrive/qi/xu/use

On dingchou (day 14), we will perform the slaughtering sacrifice to Grandfather Yi of one black bull, which is cut into halves and made as the meat-sacrifice; the Prince read the cracks and said: "On wei day there is a difficulty that may arrise, or perhaps on $x u$ day". Used.

There is one example in which the sacrifice of black bulls is seen together with the offering of jade, in particular, the jade bi-disc of yellow colour:

Huayuanzhuang: 180

甲子卜, 乙, 子啟丁璧暨玉/惠黃璧暨璧/.../辛末, 歲祖甲黑牡一, 日雨

33 The authors of the Huayuanzhuang report read the sentence “庚戌, 酊牝一” as the verification. But I still prefer to treat it as part of the charge. The traditional interpretation of the word you 酸 was "wine", but in this case it is more likely to be a verb, meaning "to cut". These inscriptions give rich information about how the animals were killed.

34 The character consists of [酉] and [馬], probably referring to a type of horse. 
jiazi/crack/yi/Zi/present/Ding/bi-disc/and/jade/hui/yellow ${ }^{35} /$ bi-disc/ and/bi-disc/.../xinwei/slaughter/Zu Jia/black/bull/one/day/rain Cracking made on jiazi (day 1), on yi day, the Prince presents to Ding the $b i$-discs and jades.

It should be yellow $b i$-discs and jade discs ...

On xinwei (day 8), we will perform the slaughtering sacrifice to Grandfather Jia of one black bull. It rains on the day.

The name Ding $\mathrm{J}$ in this inscription is significant. He appears to be the most senior person in the Huayuanzhuang inscriptions. While Chen Jian 陳劍 thinks that "Ding" was the king Wu Ding 武丁 himself, ${ }^{36} \mathrm{Li}$ Xueqin 李學勤 takes it to be an honorific name for pi 辟 or jun 君, a title for the king. ${ }^{37}$

In the Huayuanzhuang Zi-group, ritual animals of different colour are also contrasted. It seems that the preference for a particular colour was beginning to be made, as in the Li- and Wuming-groups of the kings' school. Several interesting examples are given below:

Huayuanzhuang: 278

二牛/哉, 弜侑妣庚/三牛/惠小牢, 白豘/二牢, 白豕/五豕/惠二黑牛/二黑 牛/白一豕，又出/夕白豕，羖，二牢/惠二勿牢...白豕泚庚/三羊/先也攴 白豘宜二黑牛/惠一白豕, 又災

Two/ox/roast(?)/not/sacrifice/Pi Geng/three/ox/hui/small/pennedsheep/white/sow/two/penned-ox/white/pig/five/pig/hui/two/black/ox/ two/black/ox/white/one/pig/have/aromatic-wine/evening/white/pig/ $\mathrm{ram} /$ food/two/penned-ox/hui/two/multicolour/penned-ox/ ... /white/ pig/Pi Geng/three/sheep/first/beat/white/sow/chop/two/black/ox/huil one/white/pig/have/aromatic-wine

[We will sacrifice] two oxen.

In performing the roasting rite, we will not make sacrifice to Ancestress Geng.

[We will sacrifice] three oxen.

It should be small penned sheep, and white sows.

[We will sacrifice] two penned oxen and white pigs.

[We will sacrifice] five pigs.

It should be two black oxen.

[We will offer sacrifice] two black oxen.

[We will sacrifice] one pig, which is white in colour, and additionally of aromatic wine.

35 For the decipherment of huang as a colour term, see Wang Tao, "Colour terms", esp. 89-93.

36 Chen Jian, “Shuo Huayuanzhuangdongdi jiagu buci de 'Ding' - fu shi 'su”" 說花園 莊東地甲骨卜辭的 ‘丁’ - 附釋 ‘速', Gugong bowuyuan yuankan 故宮博物院院刊 2004/3, 51-63.

37 Li Xueqin, “Guanyu Huanyuanzhuangdongdi buci de suowei 'Ding' de yidian kanfa” 關於花園莊東地甲骨卜辭所謂的“丁”的一點看法, Gugong bowuyuan yuankan 2004/5, 40-42. 
In the evening, we sacrifice white pigs and rams, and to make the yourite of two penned oxen.

It should be two multicoloured penned oxen ... and white pigs for Ancestress Geng.

[We will sacrifice] three sheep.

We will first flog the white sows, and make a meat-offering of two black oxen. It should be one white pig, and additionally of aromaticwine.

Huayuanzhuang: 459

甲子, 歲祖甲白猳一, 祐䛜一/惠黑豕祖甲。不用

jiazi/slaughter/Zu Jia/white/boar/one/offer/aromatic-wine/one/huil black/pig/Zu Jia/not/use

On jiazi (day 1), we will perform the slaughtering sacrifice to Grandfather Jia of one white boar, and offer one jar of aromatic wine. It should be black pigs for Grandfather Jia. Not used.

In these examples, the contrast is between the ritual animals of white and black colour.

Another unique feature of the Huayuanzhuang inscriptions is that many divinations mention that horses were used in sacrifice. For example:

Huayuanzhuang: 179

丙午卜, 其敕火包寧獁。用/弜灭/丁未卜, 惠邵乎包寧獁/惠虎庚乎句寧 獁/弜包黑馬。用

bingwu/crack/qi/Chi Huo/pledge/peace/x-horse/use/not/pledge/dingwei/crack/hui/shao/call/pledge/peace/x-horse/hui/Hu Geng ${ }^{38} / \mathrm{call} /$ pledge/peace/X-horse/not/pledge/black/horse/use

Cracking made on bingwu (day 43), perhaps Chi Huo will make a pledge for the tamed X-horses. Used.

We should not pledge [for the horses].

Cracking made on dingwei (day 44), it should be Shao who is called to make a pledge for tamed $\mathrm{x}$-horses.

It should be $\mathrm{Hu}$ Geng who is called to pledge for tamed horses.

We should not pledge for black horses. Used.

This inscription shows that black horses are probably less desirable to this group. As we have seen in other groups, white and reddish horses are specially pledged by the Shang kings.

There are several inscriptions that mention the killing of black horses. For example:

Huayuanzhuang: 239:

癸酉卜, 惠召...訽馬/癸酉卜, 弜刎新黑馬, 又刑/癸酉卜, 弜刎新黑[馬] 
guiyou/crack/hui/Zhao/.../split ${ }^{39} /$ horse/guiyou/crack/not/split/Xin/ black/horse/have/stab ${ }^{40} /$ guiyou/crack/not/split/Xin/black/[horse]/ ... Cracking made on guiyou (day 10), it should be Zhao to ... split the horses.

Cracking made on guiyou, we should not split black horses for Xin, and to stab them.

Cracking made on guiyou, we should not split black [horse] for Xin.

We are not sure whether the horses were killed for ancestral sacrifice, or whether they were chosen for a person or ancestor. Xin already appeared earlier in the Zi-group. The contexts here are not very clear. In the other groups, we read several examples in which the colour of horses is mentioned, but these are chariot horses, not intended for sacrifice. Archaeologists at Yinxu have found horses and chariots, mostly near the royal tombs. Horses must have been treasured at the Shang court and among the aristocratic clans, and sacrificed only for special occasions.

\section{Colour in Shang rituals: a summary}

In this section I will draw on the discussion of the evidence found in OBI, in parts 1 and 2 of this article, to argue that they point to the following conclusion: that the appearance and use of colour in the different diviner groups has revealed complex layers of meaning and pattern in the Late Shang ritual system.

Among the earliest identified inscriptions, namely those of the Shigroup, we find that white and multicolour were singled out to describe predicatively ritual animals in the context of the ancestral rite. The recipients were Grandfather Yi and other ancestors. These two colours then became dominant for the entire Yinxu period. In the Bin-group, a number of colours are associated with ancestral worship, and the contexts are much more complex than those seen in the other groups. It is noteworthy that white oxen are sacrificed to the most important ancestors of the Shang royal lineage. Some evidence even suggests that human victims of "white" skin colour were also favoured in the ancestral cult. In daily life, the king was particularly concerned with anything of white colour, i.e. the well-being of his white horses (he once dreamt of a white ox and a divination was specially made on this omen). The colour white thus seems to have had a special significance, though other colours are also important. The king made a particular effort to obtain multicoloured oxen, presumably for use at sacrificial rituals. Furthermore, in the Bin-group inscriptions, yellow and

39 The authors of the Huayuanzhuang argue that the character in this case is used as the verb wen 刎, “to split", “to cut the throat". But elsewhere in OBI the character can be read as a colour term $w u$ 勿 “multicolour"; or a verb $w u$ 物, meaning “to select". See Wang Tao, "colour terms", 20-24.

40 The character depicts a hand holding a knife over a pig, probably referring to a ritual killing, and meaning "to stab". 
dark animals are used in the rain-making ritual and in rituals performed to the cosmic spirits of the earth and the cardinal directions.

The complexity of the Shang ritual, in particular in the Wu Ding period, can be demonstrated by the existence of various diviner groups in the nonkings' school. On the whole, there is a consistency between the non-kings' inscriptions and those of the kings. White and multicoloured animals are used in ancestral sacrifices, but mythical ancestors and natural spirits are seldom offered sacrifices in the non-kings' groups and, as well as the regular recipients among the Shang ancestors, there are a few others who are not found in the main royal lineage of the Shang. There may even be some private cults in the non-kings' school. In addition to white and multicoloured ritual animals, black and red-dark animals were also frequently used for ancestral sacrifice. The unique features of the divination and ritual of the non-kings' school, and their implications, should be considered in terms of the lineage system and social structure of Late Shang society.

Following the Wu Ding period, some notable changes took place in the reign of $\mathrm{Zu} \mathrm{Jia}$, the most important of which is the emergence of the weekly cycle of regular rites (zhouji) in which regular sacrifices are made to certain ancestors on certain days. In the Chu-group, the use of colour does not appear to decrease but rather increases: the emphasis on the colour of ritual animals is very evident in this group. The divinatory charges are frequently made in paired formulae, such as: "We should sacrifice multicoloured oxen/ We should not sacrifice multicoloured oxen". Colour becomes one of the major factors in selecting ritual animals for the ancestral cult. In the Hegroup inscriptions, while evidence of coloured ritual offering is lacking, divinations are made concerning the colour of chariot-horses.

From late Wu Ding period onwards, in addition to the main diviner groups in the north branch there is a southern branch that derived from the earlier Shi-group. This branch consists mainly of the Li- and the Wuminggroups. In the Li-group inscriptions, we read that ritual animals of white colour, such as white dogs and boars, are used in exorcism and fertility rituals, particularly as blood offering.

In the exploration of colour in the Shang rituals, evidence from the Wuming-group inscriptions indicates the most significant changes. The Wuming-group is derived from the Li-group, and is parallel to the Hegroup of the north branch. Here, we first find the use of "red-yellow oxen". In the divination, red-yellow oxen become dominant and are frequently found in paired or chained charges with multicoloured ones. In some examples colour is clearly the main topic of the divination; the diviner tries to decide which colour of ox, black, red-yellow, dark-red, or yellow, should be chosen for the sacrifice. The specific ritual requirement in this case is not for a particular animal but for a particular colour. Significantly, in the Wuming-group, we read that black sheep are deliberately contrasted with white sheep in the rain-making ritual, as the colour of the animal seems to possess some magical power.

By the final phase of the Yinxu period, as the ancestral sacrifice at the Shang court developed more routines, fixed rituals were regularly performed to certain ancestors. The most important of these is the 
beng-rite performed at the sanctuary of the ancestral temples. In the inscriptions of the Huang-group (a combination of the He-group of the north branch and Wuming-group of the south branch), the number, combination and colour of ritual animals remain significant factors. Horses of various colours are the subject of divination, and in some inscriptions we read that white deer and buffaloes captured in hunting expeditions are sacrificed at special ceremonies. But in the numerous inscriptions in which animals of various colours have been chosen for sacrifice, the red-yellow oxen seem to have become the most important. There was, it seems, some discrimination between the red-yellow and the multicolour (see Figure 1).

We have thus seen that at least six or seven colour categories are distinguished in OBI and that the use of coloured ritual offerings reveals that colours hold some underlying meaning. For instance, the colour white is significant in Shang rituals, with sacrifices (animal, human, grain, jade) of white colour being frequently offered at ancestral, exorcist and fertility rites. In particular, the recipients of the white ox are usually the "High Ancestors" or otherwise important. In this respect, it is worth comparing the meaning of "white" in Shang culture with its role in the Ndembu culture. The anthropologist Victor Turner found that colour symbolism plays an important part in Ndembu society. In Ndembu ritual, white can have many meanings, including goodness, strength and health, purity, good-fortune, chieftainship, meeting with ancestor spirits and offering to ancestors life, generosity, sociability, fertility, maturity, and making visible or revealing something. "Behind the symbolism of whiteness ... lay the notions of harmony, continuity, purity, the manifest, the public, the appropriate, and the legitimate." ${ }^{41}$ Other colours, such as yellow and dark, may also be associated with magic.

The Yinxu period lasted over 200 years, and during that time the meaning of colour changed as society and the ritual system itself changed. First, there is the shifting emphasis from white to red, which is the most significant step. Traditionally, red or red-yellow has been particularly assigned to the Zhou, as white is particularly assigned to the Shang. Many scholars believe that when the Zhou conquered the Shang in 1045 BCE, the political change ushered in a change in the cultural landscape. However, Shang and Zhou inscriptions and archaeological evidence both show that the relationship between the Shang and the Zhou is much closer than previously believed. ${ }^{42}$ The Zhou inherited the Shang tradition, and many basic features of the early Western Zhou institutions were not invented by the Zhou people themselves, but derived originally from the Shang system. For instance, according to a study by Liu Yu 劉雨, there are about twenty forms of rites recorded in the bronze inscriptions before King Mu's 穆王 reign (c. 947-928 BCE), and seventeen of these can be identified with the

41 Victor W. Turner, The Forest of Symbols: Aspects of Ndembu Ritual (Ithaca, NY and London: Cornell University Press, 1967), 77.

42 See Zhang Guangzhi 張光直 [K. C. Chang], "Yin Zhou guangxi de zai jiantao" 殷 周關係的再檢討, Zhongguo qingtong shidai 中國青銅時代 (Beijing: Sanlian shudian, 1983), 81-106. 


\begin{tabular}{|c|c|c|c|c|}
\hline Diviner group & Sacrifices & Recipients & $\begin{array}{l}\text { Contexts and } \\
\text { methods }\end{array}$ & Other \\
\hline Shi-group & $\begin{array}{l}\text { white hogs, } \\
\text { multicoloured } \\
\text { oxen }\end{array}$ & $\begin{array}{l}\text { X-Geng, } \\
\text { Xiang Jia }\end{array}$ & ancestral rite & \\
\hline Bin-group & $\begin{array}{l}\text { white pigs, } \\
\text { white oxen, } \\
\text { white men, } \\
\text { white Qiang- } \\
\text { men, } \\
\text { multicoloured } \\
\text { oxen (bulls } \\
\text { and cows), } \\
\text { yellow oxen } \\
\text { and zhi-goat }\end{array}$ & $\begin{array}{l}\text { Fu Yi, Pi Ji, } \\
\text { Wang Hai, Da } \\
\text { Jia, Nao(?), } \\
\text { Ding } \\
\text { fang- } \\
\text { directions and } \\
\text { the altar of } \\
\text { earth }\end{array}$ & $\begin{array}{l}\text { ancestral rite, } \\
\text { di-rite } \\
\text { (slaughtering, } \\
\text { burning, blood- } \\
\text { taking) }\end{array}$ & $\begin{array}{l}\text { white oxen } \\
\text { appear in } \\
\text { dreams; } \\
\text { multicoloured } \\
\text { oxen sought in } \\
\text { various places; } \\
\text { white horses } \\
\text { sent in to be } \\
\text { chariot-horses; } \\
\text { divining on } \\
\text { the well-being } \\
\text { of white } \\
\text { horses and the } \\
\text { colour (white) } \\
\text { of unborn } \\
\text { horses }\end{array}$ \\
\hline Chu-group & $\begin{array}{l}\text { white pigs, } \\
\text { white oxen } \\
\text { (bulls), } \\
\text { multicoloured } \\
\text { oxen, dark- } \\
\text { reddish } \\
\text { multicoloured } \\
\text { oxen, } \\
\text { yellowish } \\
\text { multicoloured } \\
\text { oxen }\end{array}$ & $\begin{array}{l}\mathrm{Zu} \mathrm{Yi,} \mathrm{Zu} \\
\text { Xin, Fu Ding, } \\
\text { Pi Geng }\end{array}$ & $\begin{array}{l}\text { ancestral rite } \\
\text { (slaughtering } \\
\text { and } \\
\text { dismembering, } \\
\text { libation) }\end{array}$ & \\
\hline He-group & & & & $\begin{array}{l}\text { divining on } \\
\text { the reddish- } \\
\text { coloured, } \\
\text { chariot-horse }\end{array}$ \\
\hline Li-group & $\begin{array}{l}\text { white sheep, } \\
\text { white pigs } \\
\text { (boars and } \\
\text { piglets), white } \\
\text { oxen, } \\
\text { multicoloured } \\
\text { oxen, red- } \\
\text { yellow oxen, } \\
\text { red-dark oxen, } \\
\text { white millet }\end{array}$ & $\begin{array}{l}\text { Fu Yi, Da Yi, } \\
\text { Zu Yi, Zu } \\
\text { Xin, Pi Geng, } \\
\text { Pi Bing, } \\
\text { Shang Jia }\end{array}$ & $\begin{array}{l}\text { ancestral and } \\
\text { fertility rites, } \\
\text { exorcism ritual } \\
\text { (burning, } \\
\text { blood-offering) }\end{array}$ & $\begin{array}{l}\text { white foxes } \\
\text { caught in } \\
\text { hunting }\end{array}$ \\
\hline Wuming-group & $\begin{array}{l}\text { white oxen, } \\
\text { red-yellow } \\
\text { oxen, red-dark } \\
\text { oxen, yellow } \\
\text { oxen, black } \\
\text { oxen, white } \\
\text { sheep, black } \\
\text { sheep }\end{array}$ & $\begin{array}{l}\text { Zu Yi, Zu } \\
\text { Xin, Pi Gui, } \\
\text { Pi Xin, Pi } \\
\text { Geng, Shang } \\
\text { Jia, }\end{array}$ & $\begin{array}{l}\text { ancestral rite, } \\
\text { rain-making } \\
\text { ritual }\end{array}$ & \\
\hline Huang-group & $\begin{array}{l}\text { red-yellow } \\
\text { oxen, } \\
\text { multicoloured } \\
\text { oxen, white } \\
\text { unicorn } \\
\end{array}$ & $\begin{array}{l}\text { Wu Ding, Wu } \\
\text { Yi, Zu Jia, Da } \\
\text { Yi }\end{array}$ & & $\begin{array}{l}\text { white deer, } \\
\text { foxes, and } \\
\text { rhinoceros } \\
\text { caught in } \\
\text { hunting }\end{array}$ \\
\hline $\begin{array}{l}\text { non-kings' } \\
\text { school (Wu, Zi, } \\
\text { Feiwang } \\
\text { Wuming, and } \\
\text { Huayuanzhuang- } \\
\text { Zi groups) }\end{array}$ & $\begin{array}{l}\text { white pigs, } \\
\text { white sheep, } \\
\text { multicoloured } \\
\text { oxen (bulls), } \\
\text { black bulls }\end{array}$ & $\begin{array}{l}\text { Zi Chou, Zi } \\
\text { Geng, Zi Chi, } \\
\text { Fu Jia, Fu } \\
\text { Ding, Pi } \\
\text { Geng, Zu Yi }\end{array}$ & $\begin{array}{l}\text { ancestral rite, } \\
\text { exorcist rite } \\
\text { burning rite }\end{array}$ & \\
\hline
\end{tabular}


Shang rites recorded in the oracle bone inscriptions. This shows that the Zhou rulers followed much of the Shang ritual system, albeit with slight modifications ${ }^{43}$ Between the Shang and Zhou ritual systems there is clearly a historical, as well as a structural, link. This study has shown that the dominance of red was passed down from the Shang to the Zhou, and that by studying colour in the Shang and Zhou rituals, we may gain a better understanding of the cultural development during this "transitional" phase.

Second, the change in attitude towards $w u$-multicolour also indicates the internal development of the Shang colour system. In the early Yinxu period, at least in the Shi- and Bin-groups, we have found no evidence to suggest a strong preference for white over multicolour. But by the late Yinxu period, in particular in the He-, Wuming- and Huang-groups, multicoloured sacrifice is often contrasted with the use of animals of reddish colour, and one can detect some discrimination against the former. This shows that, in a different context, multicoloured animals had become inferior to those of pure colour for ritual purposes. This is not because of what the sacrifical animals are, but because they symbolize a ritual impurity.

The use of colour in Shang ritual may reflect, to a degree, society as a whole. The Shang perception of the supernatural, and the ritual system they designed for it, are in part the result of a social process. Although the social structure of the Late Shang dynasty is still a topic open to scholarly debate, there are many grounds to believe that it was a complex society with a hierarchical social order for the living as well as for the dead; some distinctions were beginning to be made for the world of their gods, spirits and the ancestors. The selection of the colour, like the selection of the sex and number of ritual animals, could act as the agency of such a process.

\section{Shang colour symbolism: an interpretation}

The use of ritual animals in Shang sacrifices and the preparation and methods of rituals are complex. In many cases we can only guess at their meanings, which always seem to have some symbolic or sympathetic sense. From the OBI, we can see that the selection of the ritual victims involved great care in the choice of type, sex, number, combination and colour of ritual animals. Shang rituals are full of symbolic actions. For instance, when asking for rainfall, the Shang diviners liked to perform dancing and burning rituals in which the victim was plunged into the river.

As far as the general theory of ritual and sacrifice is concerned, some useful anthropological studies have been offered. Many scholars, probably influenced by Henri Hubert and Marcel Mauss, believed that ritual and sacrifice help to distinguish between the sacred and profane, and to communicate between the living and the gods; and that the sacrificial rite aimed to expiate sins.$^{44}$ But the once popular theory was, as modern critics

43 See Liu Yu, "Xizhou jingwen li de jizuli" 西周金文裏的祭祖禮, Kaogu Xuebao 1989/4, 495-522.

44 Henri Hubert and Marcel Mauss, Sacrifice: Its Nature and Function (tr. W.D. Hall, repr. London: Cohen and West, 1964), esp. 95-103. 
have now realized, formulated not without a certain degree of IndoEuropean ethnocentrism. The interpretation of an expiatory rite or sacrifice for "sin" is more relevant to Greek mythology and Roman religion, or to Christianity, than to early Chinese religion. From a socio-psychological point of view, a new theory for ancient China is that ritual and sacrifice would release internal tensions; in other words, a society diverts its violence by seeking a ritual victim in order to protect the community and to establish a sense of unity. ${ }^{45}$

Colour played an important role in many early religious systems. ${ }^{46} \mathrm{~A}$ ritual action or a particular practice may reflect a symbolic code of communication between the rituals and the spirits which the diviners believed to be effective. As Mauss once pointed out, the divinatory rite is not isolated, but is a part of a whole; the task of the diviner is to relate different groups of things to each other based on a system of classification. Colour has a particular role to play, "whereby, out of a whole series of possible characteristics, colour is chosen to establish a relationship between two things". ${ }^{47}$ In other words, the colour chosen for a particular ritual animal reflected, to a certain degree, the symbolic interaction between the sacrifice and the recipients. Thus, although the particular meanings attached to a certain colour could vary enormously in different times and places, or among different individuals, in many cases the choice of colour meanings does not appear to be purely arbitrary, but rather conditioned or motivated. Colour symbolism thus becomes collective and is codified in a specified cultural context, particularly in a religious system. ${ }^{48}$

Thus, colour occurs, as Edmund Leach has pointed out, in sets, and the meaning of a particular symbol can only be understood in contrast with other symbols; similarly, individual symbols have layers of meaning which depend upon what is being contrasted with what. ${ }^{49}$ From a semiotic point of view, Umberto Eco makes the point even more explicitly:

When one utters a colour term one is not directly pointing to a state of the world (process of reference), but, on the contrary, one is connecting or correlating that term with a cultural unit or concept. The utterance of the term is determined, obviously, by a given sensation, but the transformation of the sensory stimuli into a percept is in some way determined by the semiotic relationship between the

45 René Girard, Violence and the Sacred, tr. R. Brain (repr. Baltimore and London: Johns Hopkins University Press, 1977), esp. 4-27. In his study of ritual violence in ancient China, Mark Lewis has developed this theory and thrown new light on the study of early Chinese religion; see Mark Lewis, Sanctioned Violence in Early China (Albany, NY: SUNY Press, 1990).

46 For an early study of the subject, see Donald A. MacKenzie, "Colour symbolism", Folklore 33/2 (1922), 136-69.

47 Marcel Mauss, A General Theory of Magic, tr. R. Brain (London: Routledge and Kegan Paul, 1972), 77.

48 M. Sahlins, "Colors and cultures", Semiotica 16 (1976), 3, 1-22.

49 Edmund Leach, Culture and Communication: The Logic by Which Symbols Are Connected (Cambridge: Cambridge University Press, 1976), 57-60. 
linguistic expression and the meaning or content culturally correlated to it. $^{50}$

Animals are naturally of different colours. But when we read that the Shang people offered a specific animal of a specific colour, such as a "white ox" or a "black sheep", how can we determine whether that colour carried a special meaning? Previously, scholars have overlooked the significance of colour in Shang rituals. Though some have referred to the matter, they generally failed to recognize that an underlying colour system might have existed. For example, the Taiwanese scholar Huang Ranwei 黃然偉 dismissed the traditional view that "the Shang gave pre-eminence to white (Yin shang bai 殷尚白)”, on the grounds that they used ritual animals of various colours. ${ }^{51}$ In 1968, Zhang Bingquan 張秉權 also undertook a comprehensive study of sacrificial animals recorded in OBI, but did not recognize the significance of the colour of ritual animals. He wrote: "In terms of the skin colours [of animals], although they sometimes were specially indicated as being black, or white, or yellow, we cannot see that there was any particular meaning in this". ${ }^{52}$ To him, colour was simply a natural attribute of the animals and the colour chosen for the sacrifice was therefore meaningless. The shortcomings of their arguments lie essentially in their supposition that colour was a random and accidental phenomenon. They failed to see the colour of ritual animals as a meaningful code which might be explained within the Shang ritual system. One of the reasons for this is probably the recognition that the later colour code associated with the Five-Phases Theory (Wuxingshuo 五行 說) had not been established in the Shang period. Although this is certainly true, what we have seen here is an earlier colour system that may be understood as a forerunner of the later self-conscious theory.

To interpret the meaning of colour in Shang ritual we must draw on a cross-cultural approach. There are a number of anthropological and folklore studies of colour symbolism in Asia, Europe, Australia and Africa that may throw light on Shang colour symbolism. ${ }^{53}$ As was the case in ancient and medieval Europe, ${ }^{54}$ colour implies certain meanings and is effective in magic rituals. For instance, Axel-Ivar Berglund has observed that the colour of animals is part of a symbolic system in Zulu thought. In rain-making rituals, the hornbill is offered to the Rain Princess in the sky, and a black sheep is sacrificed to the Python God, the male counterpart of

50 Umberto Eco, "How culture conditions the colours we see", in Marshall Blonsky (ed.), On Sign: A Semiotics Reader (Oxford: Blackwell, 1985), 157-75.

51 Huang Ranwei, Yinli kaoshi 殷禮考實 (Taipei: Taiwan daxue, 1967), esp. 6-18.

52 Zhang Bingquan, “Jisi buci zhong de xisheng”祭祀卜辭中的犧牲, Zhongyang yanjiuyuan lishi yuyan yanjiusuo jikan 3 中央研究院歷史語言研究所集刊 3 (Taipei, 1968), 181-237. Yang Shuda 楊樹達 also wrote a lecture on the colour of Shang ritual animals when he was teaching at Hunan University in the 1940s, but no copy of this paper has been traced.

53 A more recent study is John Hutchings, Munehira Akita, Noriko Yoshida and Geraldine Twilley, Colour in Folklore, with Particular Reference to Japan, Britain and Rice (London: The Folklore Society, 1996).

54 For a reference, see Wilfrid Bonser, "The significance of colour in ancient and mediaeval magic: with some modern comparisons", Man 25 (1925), 194-8. 
the Rain Princess on earth. ${ }^{55}$ In Zulu ancestor worship, the ox has the greatest prestige, and is thought to mediate between lineage and ancestors. It is also interesting that, for the Zulus, the ancestors and the underworld are all "white". ${ }^{56}$ In different rituals, the methods of ritual killing and disposal of remains are also specified: slaughter, cooking, the licking off of fat and burial in the earth. ${ }^{57}$ When we compare Shang colour symbolism with that of other cultures, we assume that such a comparison might enrich our understanding of the complex meaning of colour. It is not enough merely to spot similarities.

Indeed, the most illuminating studies may be the ethnographic work carried out in remote areas of China. Shamanism used to be the foundation of the religious life of the people of northern China who speak an Altaicbased language. In shamanistic rituals the colour of animals is full of meaning. The Evenki (Solon), for example, often perform a wumai-rite ("calling the souls") when children are ill. The ritual animals are deer and elks: "in the evening, before the Shaman dances in a trance, first a black deer is killed for the Shaman to ride to the other world; ... the next day, a white deer is slaughtered to offer to the ancestors' spirits". ${ }^{58}$ The Wa people (a language of the Mon-Khmer family) who live a fairly isolated life in Yunnan Province, south-western China, have a population of about 0.3 million and still practise many primitive forms of religious activity. When ever there is an important religious event relating to, say, heaven worship, they perform a ritual slaughtering of oxen. The oxen are selected by type and colour, with a noticeable preference for those of dark-red colour. ${ }^{59}$ The Yi (Lolo) people, who live in the mountainous areas of Yunnan, speak a language with Tibeto-Burman roots and have a strong religious tradition as well as many sophisticated rituals. The use of ritual animals in their ancestral cult has been vividly described by the Yi priest, Jike Erda Zehuo. ${ }^{60}$ As part of the ritual, the slaughtered animals would be laid out in rows for sacrificing to the ancestors according to their "qualifications". The term "qualification" refers to their type, size and number. Although there is little emphasis on the colour of the ritual animals, it is none the less quite a striking feature of many of the rituals described. In the ji'er-rite ("to expel evils"), the ritual animals are a cockerel, a boar, a ram, and a cow which must be black. In other rites, such as blessing and congratulatory rituals, white animals seem to be favoured. The priests believe that the ritual animals form the key factor

55 A.-I. Berglund, Zulu Thought-Patterns and Symbolism (London: C. Hurst \& Co., 1975), 51-63.

56 ibid., $167,371$.

57 ibid., $214-40$.

58 Cai Jialin 蔡家麟, “Zhongguo beifang minzu de samanjiao”中國北方民族的薩滿 教, in Zhongguo shaoshu minzu zongjiao 中國少數民族宗教, ed. Song Enchang 宋恩 常 (Kunming: Yunnan renmin chubanshe, 1985), 27.

59 Based on my personal observation in the 1980s.

60 Wo zai guisheng zhijian: yige Yizu jisi de zishu 我在鬼神之間: 一個族祭司的自述, narrated by Jike Erda Zehuo 吉克尔達則伙, recorded by Jike Zehuo Shihuo 吉克 則伙 世火, and edited by Liu Yaohan 劉堯漢 (Kunming: Yunnan renmin chubanshe, 1990), 71-112. This book describes the rituals in vivid detail, and I have selectively translated from the descriptions relating to ritual animals. 
in the rise and decline of the clan: if the ritual animal is plump, descendants will be prosperous; if it is healthy and strong, descendants will be clever and handsome; if it is emaciated or maimed descendants will be weak or disabled. ${ }^{61}$

The most important study on colour in sacrifice, both in terms of its ethnographic and theoretical impact, is probably Victor Turner's anthropological work on Ndembu colour symbolism. ${ }^{62}$ Turner found that colour symbolism plays an important part in the Ndembu ritual system. Three basic colours - white, red and black - make up the core of the colour symbolism. In Ndembu language, most colour terms are derived from white, red and black, and these three colours have a set of complex meanings in their ritual contexts. ${ }^{63}$ Turner also suggested that the physical experience associated with different colours reflects the human experience of social relationships. In this way, colours provide a kind of primordial classification of reality. ${ }^{64}$

When we try to interpret symbolism, however, we must be aware of the nature of the symbolism itself. As Daniel Sperber has argued, the study of symbolism should also be based on human cognitive development, because symbolism is not only a kind of conceptual representation, but a process of cognitive categorization and symbolization. ${ }^{65}$ More recently, George Lakoff has argued forcefully that symbolic interaction, such as that based on colour, is more directly involved with imagery, perception and bodily experience than with language and logic. ${ }^{66}$ In view of the immediate cognitive and cultural significance processed by colour, a systematic study of its orientation in a given historical period, based on archaeological material, will undoubtedly contribute to our understanding of colour symbolization in general. With this in mind, the present paper has attempted to interpret how Shang colour symbolism, or more precisely, the use of ritual animals of certain colours, was activated in a non-literal context.

The comparison between Shang colour symbolism and later traditions provides us with a good example of the conceptual development of symbolization in early China. The use of colour in OBI is rich, and a close examination reveals that a pattern indeed existed: colour in Shang rituals is meaningful and, to a degree, is symbolic and interrelated. The Shang diviners themselves, however, did not write any explanatory notes of why there was a preference for certain colours. It is very difficult to describe the

61 ibid., 90, 92, 94.

62 Turner, The Forest of Symbols, esp. ch. 3, 59-92.

63 ibid., 69-71.

64 ibid., 89-90.

65 Daniel Sperber, Rethinking Symbolism (Cambridge Studies in Social and Cultural Anthropology. Cambridge: Cambridge University Press, 1975).

66 For further discussion of this subject see George Lakoff, Women, Fire, and Dangerous Things: What Categories Reveal about the Mind (Chicago and London: University of Chicago Press, 1987), esp. preface and 12-57; also Francisco J. Varela, Evan Thompson and Eleanor Rosch, The Embodied Mind: Cognitive Science and Human Experience (Cambridge, MA and London: MIT Press, 1991), 157-71. 
precise contents of the symbolic codes of colour, because the so-called symbolism was still implicit and sometimes hidden in concrete images.

However, in the late texts, the meaning of colour became much more codified: different colours were clearly related to different gods. In other words, the symbolic meaning of colour in these texts is obvious and pronounced. Thus, we are probably dealing with symbolism on two different levels: one is an explicit, theorized level recorded in the texts; and the other an ambiguous, practical level underlying the ritual practice. In other words, certain religious discourse and action may originally have been "symbolic" and then later have become "literalized". ${ }^{67}$

The comparison between Shang colour categorization and symbolism is very important in understanding the correlative system-building of the wuxing theory. There is obviously a structural similarity between this model and the later "Five Phases" scheme. In other words, the wuxing colour scheme may have derived from the Shang colour categorization. By reconstructing the Shang colour categorization and by examining the evidence of the use of colour in Shang ritual, it is clear that the Shang had already laid the foundation for the later correlative system-building.

Based on Jack Goody's argument, both John Henderson and Sarah Allan take the view that the main reason for the correlative system-building in early China was the much wider use of literacy in the Eastern Zhou period (8th-3rd centuries BCE); ${ }^{68}$ and Allan says: "Literature led not only to doubt, but also to theorization. Opposition and patterns of organization which were implicit in Shang thought came to be recognized and made explicit. Correlative thinking was not abandoned, but systematized and made into a seemingly scientific system." 69

Previously, scholars have simply used textual evidence, in particular philosophical texts, as the criteria for dating the wuxing theory, without realizing that the formation of the theory is a long and complex process, with deep roots in various traditions and social practice. Now, when reconsidering the case of the origins and development of the wuxing theory in Chinese thought, we can no longer afford to ignore the evidence from archaeology and Shang oracle bone inscriptions.

67 In his book Theory and Symbolism (Cambridge: Cambridge University Press, 1976), John Skorupski has made a convincing argument that it is necessary to distinguish between an explicit, literal level of religious belief and practice and a symbolic level of which the actors themselves are not aware.

68 See John B. Henderson, The Development and Decline of Chinese Cosmology (New York and Guildford: Columbia University Press, 1984), esp.1-46; Sarah Allan, The Shape of the Turtle: Myth, Art, and Cosmos in Early China (Albany, NY: SUNY Press, 1990), 13-4, 174-6.

69 Allan, ibid., 176. 